\title{
Martensite in Steels: its Significance, Recent Developments and Trends
}

\author{
A.S. Schulz-Beenken \\ Universität-GH Paderborn, At. Soest, Lübecker Ring 2
}

\begin{abstract}
Martensite is generally known as a hard but brittle microstructure. This is only true for high carbon plate martensite. Recently developed steels with a lath martensite microstructure offer an excellent toughness at yield strength of $1000 \mathrm{MPa}$ yield strength. A transformation into lath martensite by glide as invariant shear mechanism is only possible at a carbon content below 0,03 $\%$. The source of both high strength and good toughness is the high dislocation density and the narrow lath width off less than $1 \mu \mathrm{m}$. By a thermomechanical treatment, that leads to a finer lath structure both strength and ductility can be improved to a yield strength of $1150 \mathrm{MPa}$ and an elongation of $18 \%$.

As, unlike high carbon plate martensite, the hardness of lath martensite is not achieved by the distortion of the tetragonal cell by carbon atoms, the hardness of lath martensite remains stable up during an annealing treatment up to $600^{\circ} \mathrm{C}$. This thermal stability of the lath martensit microstructure makes an additionai increase of hardness by the precipitation of different types of intermetallic phases possible. The increase of the hardness from $300 \mathrm{HV}$ to $600 \mathrm{HV}$ by precipitation without volume changes and good cold deformability reveals many new application in manufacturing.

In plate martensite too, comparatively high toughness values can be achieved, if carbon is replaced by nitrogen. The refining influence of nitrides on the austenite grain sizes and the precipitation of fine nitrides during the annealing process leads to impact values three times higher than those of comparable high carbon plate martensite.
\end{abstract}

\section{INTRODUCTION}

To accomplish the demands of light-weight construction all possible mechanisms as precipitation hardening, solid solution hardening and grain refinement have been used to develop high-strength steels. The only option for a further increase in yield and tensile strength is the martensite transformation hardening. However most new applications for high-strength material require high toughness. As martensite is generally known as a hard but brittle microstructure, its application was limited to tool steels or tempering steels. These steels require an additional, well defined tempering treatment to achieve an adequate toughness.

Low toughness values were only found in high carbon plate martensite. Steels with a lath martensite microstructure offer an excellent toughness at yield strength of about $1000 \mathrm{MPa}$. As this combination of high strength an good toughness is achieved in the as-quenched state without any further tempering treatment [1], lath martensite requires less costs for heat treatment as conventional tempering steels.

The transformation into lath martensite by glide as invariant shear mechanism is only possible at a carbon content below $0,03 \%$. By addition of $\mathrm{Ni}, \mathrm{Mn}, \mathrm{Cr}$ or $\mathrm{Mo}$, the critical cooling rate can be reduced, so that 
the formation of ferrite or bainite can be prevented. As the influence of $\mathrm{Ni}$ is most distinct, lath martensite was first examined in Ni-alloyed steels. Unlike plate martensite, its lattice was not tetragonal but cubic[2] as no carbon distorts the lattice.

The lath martensite microstructure (figure 1) is characterised by packets of parallel blocks [3]. The blocks consist of a large number of laths. Inside the laths a high dislocation density can be observed (figure 2). During a tempering treatment of lath martensite, no volume changes have been measured and the hardness of lath martensite maintains constant up to temperature of $700^{\circ} \mathrm{C}$ (figure 3 ). No recrystallisation and no annihilation of dislocations is observed [4]. This thermal stability is of the carbon free lath martensite microstructure has been used to achieve a further increase of strength by the precipitation of intermetallic phases [5]. The tensile strength of these alloys, called Maraging Steels, reached up to $3000 \mathrm{MPa}$ at a total elongation of $2,5 \%[6]$.

Maraging Steel have a rather high Ni-content of $18 \%$, only some high-temperature Maraging Steels have a lower $\mathrm{Ni}$ content of $12 \% \mathrm{Ni}$ [7]. To reduce the alloying costs, Ni was replaced by $\mathrm{Mn}$ [8]. Steels, where $\mathrm{Ni}$ had been partially replaced, show the same lath martensite structure and had about the same mechanical properties in the as quenched as in the age-hardened state [9]. Steels where $\mathrm{Ni}$ is totally replaced by $10 \% \mathrm{Mn}$ exhibit the same micro structure and mechanical properties in the as quenched state as Ni-Maraging Steels. However the hardening in Fe-Mn-lath martensite is distinctly inferior.

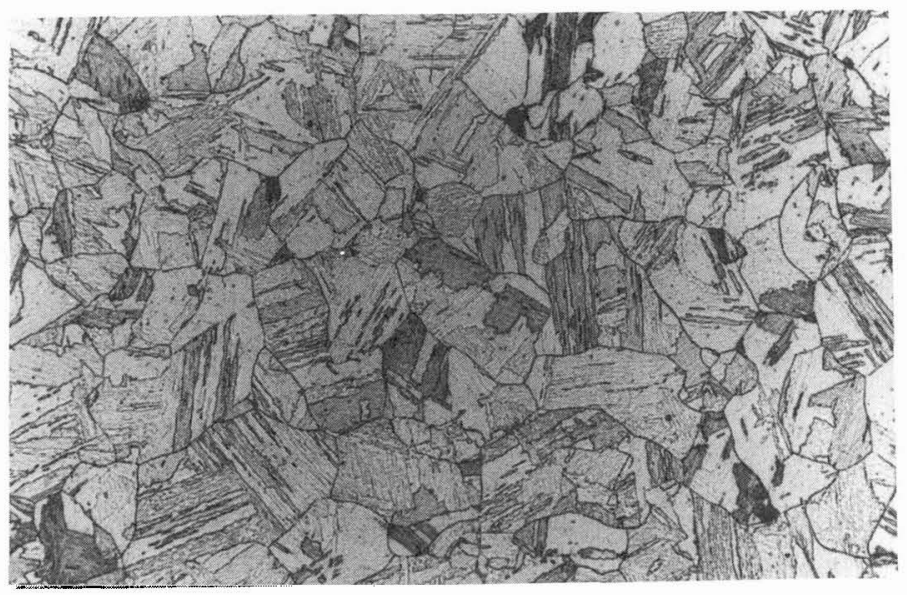

Figure 1: Lath martensite microstructure
$50 \mu \mathrm{m}$

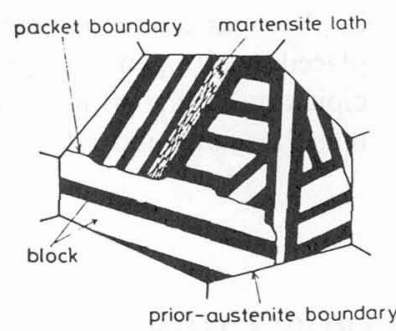

schematic illustration

The source of both high strength and good toughness is the high dislocation density and the narrow lath width [10]. Naylor [11] defined the grain size as the mean slip length within a lath. The slip length within a lath can be calculated for a lath length of about $40 \mu \mathrm{m}$ and a width of about $0,4 \mu \mathrm{m}$ will be $1.5 \mu \mathrm{m}$, which is rather small compared to other microstructures [12]. By a thermomechanical treatment, that leads to shorter length of the laths, both strength and ductility can be improved [13]. 


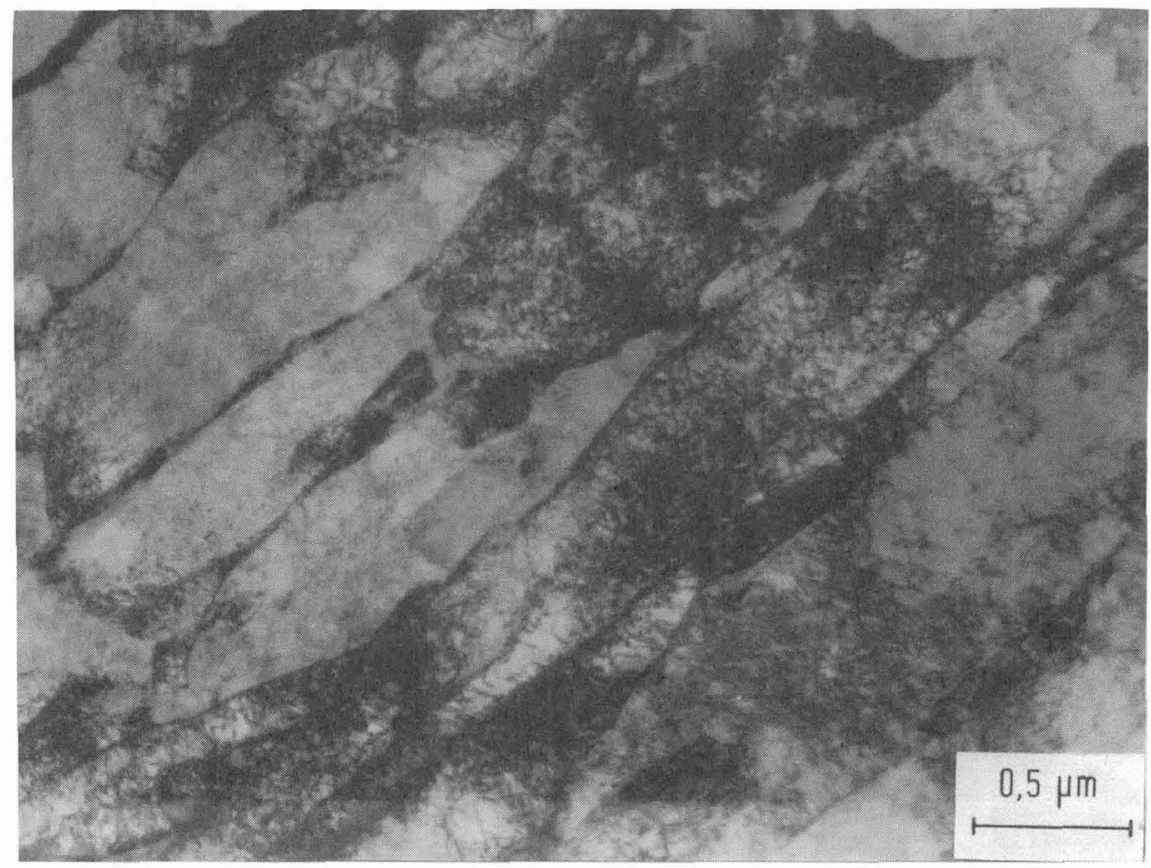

Figure 2: Transmission electron micrograph of a low alloyed lath martensite.

Chemical composition: $2 \% \mathrm{Mn}, 2 \% \mathrm{Cr}, 1 \% \mathrm{Ni}, 1 \% \mathrm{Mo}, 0,03 \% \mathrm{C}$

\section{RECENT DEVELOPMENTS}

\subsection{Low alloyed Lath Martensite}

In the course of the development of high strength bainitic steels it was evident that a transformation into lath martensite was possible at low $\mathrm{Ni}$ and $\mathrm{Mn}$ concentrations. An alloy content of $2 \% \mathrm{Cr}, 2 \% \mathrm{Mn}$ and 1 $\% \mathrm{Ni}$ at Carbon content of $0,03 \%$ is sufficient to avoid a ferrite or bainite transformation. The microstructure of this steel, characterised by bundles of parallel laths is shown in figure 2 . The mechanical properties, measured in a tensile test and the ductile to brittle transition temperature, measured in an impact test at room temperature are given in table 1 [13].

A thermomechanical treatment at a comparatively low rolling temperature of $750^{\circ} \mathrm{C}$ and a subsequent rapid cooling reduces the length of the laths to $2 \mu \mathrm{m}$, while the width remained constant at a value of 0,2 $\mu \mathrm{m}$. This reduction of the lath length improves the yield strength and particularly the toughness (figure 3 ). The impact transition temperature from ductile to brittle fracture (DBTT) was reduced from $-80^{\circ} \mathrm{C}$ to$160^{\circ} \mathrm{C}$, which is far better than most of the industrial requirements. The yield strength increased from 660 $\mathrm{MPa}$ to $920 \mathrm{MPa}$ and the ultimate tensile strength from $960 \mathrm{MPa}$ to $1130 \mathrm{MPa}$ (table 1) [13]. 
Table 1: Mechanical properties of low alloyed lath martensite [13].

Chemical composition: $2 \% \mathrm{Mn}, 2 \% \mathrm{Cr}, 1 \% \mathrm{Ni}, 1 \% \mathrm{Mo}, 0,03 \% \mathrm{C}$

\begin{tabular}{|c|c|c|c|c|c|c|c|}
\hline $\begin{array}{c}\text { low alloyed } \\
\text { Lath Martensite }\end{array}$ & $\mathrm{R}_{\mathrm{p} 0,2}$ & $\mathrm{Rm}$ & $\mathrm{A}_{5}[\%]$ & $\mathrm{Ag}[\%]$ & $\mathrm{Z}[\%]$ & $\mathrm{HV}$ & $\mathrm{DBTT}$ \\
\hline as quenched & $660 \mathrm{MPa}$ & $960 \mathrm{MPa}$ & 17 & 10 & 75 & 295 & $-80^{\circ} \mathrm{C}$ \\
\hline $\begin{array}{c}\text { after thermomechanical } \\
\text { treatment }\end{array}$ & $920 \mathrm{MPa}$ & $1130 \mathrm{MPa}$ & 16 & 10 & 70 & 310 & $-160^{\circ} \mathrm{C}$ \\
\hline
\end{tabular}
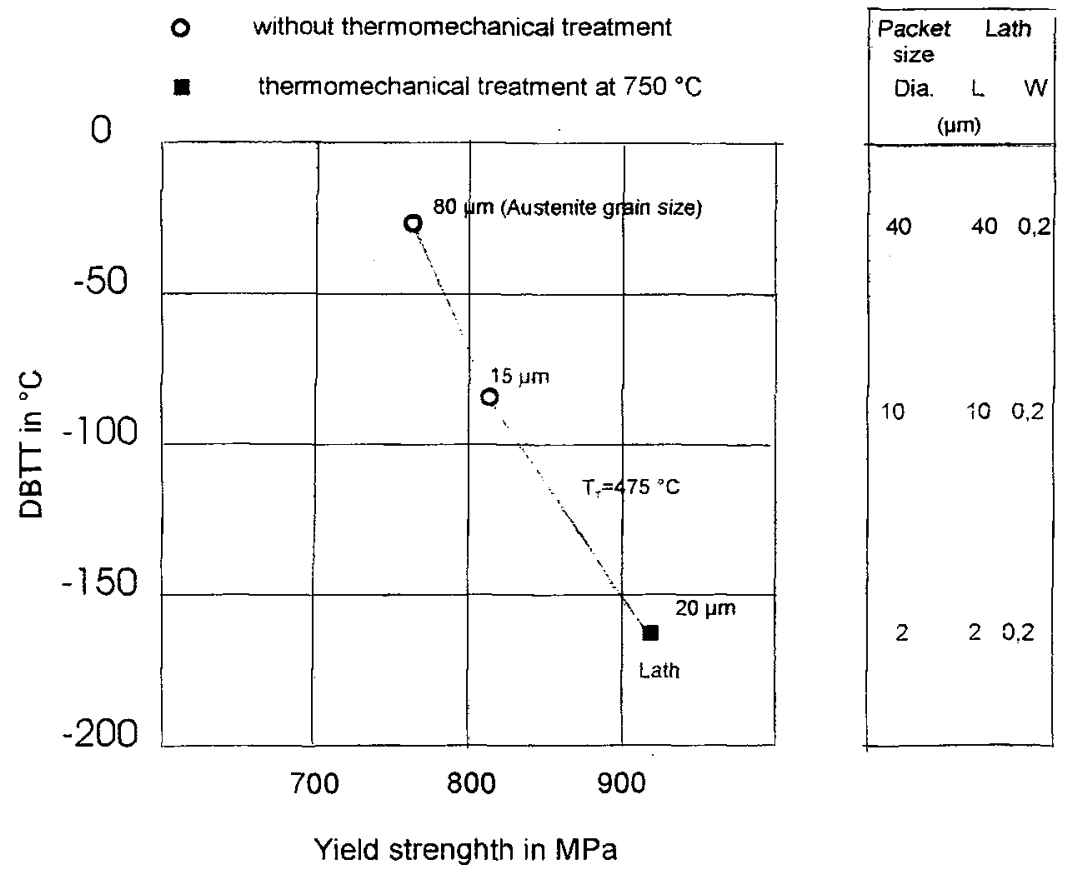

Figure 3: Influence of the austenite grain size, lath width and length and the packet size on the yield strength and the ductile to brittle transition temperature (DBTT)

As, unlike high carbon plate martensite, the hardness of lath martensite is not achieved by the distortion of the tetragonal cell, the hardness of lath martensite remains stable up during an annealing treatment up to $600^{\circ} \mathrm{C}$. This thermal stability of the lath martensite microstructure makes an additional increase of hardness by the precipitation of different types of intermetallic phases possible [14]. The increase of the hardness from $300 \mathrm{HV}$ to $600 \mathrm{HV}$ by precipitation without volume changes reveals many new application in manufacturing.

\subsection{Age-Hardening of low alloyed Lath Martensite by coherent Intermetallic Phase}

As no precipitation of carbides is possible at a low carbon content of $0,03 \%, 2 \% \mathrm{Si}$ and $1 \% \mathrm{Ti}$ are added to increase the tensile strength by the precipitations of the coherent intermetallic phase (Fe,Ni) ${ }_{16} \mathrm{Ti}_{6} \mathrm{Si}_{7}$, 
the G-phase [15]. Additionally the Mn content was increased to $4 \%$ and the $\mathrm{Ni}$ content to $3 \%$ to compensate the ferrite stabilising effect of $\mathrm{Si}$ and $\mathrm{Ti}$. In the as quenched state this steel showed about the same mechanical properties as the low alloyed lath martensite quoted in table 1. By age-hardening the hardness can be increased from $300 \mathrm{HV}$ to $600 \mathrm{HV}$ (figure 4) and a tensile strength of $2000 \mathrm{MPa}$ can be achieved (table 2).

Table 2: Mechanical properties in the age-hardened state of low alloyed lath martensite and two Maraging Steels

\begin{tabular}{|c|c|c|c|c|}
\hline & $\mathrm{R}_{\mathrm{p} 0,2}[\mathrm{MPa}]$ & $\mathrm{Rm}[\mathrm{MPa}]$ & $\mathrm{A}[\%]$ & $\mathrm{HV}$ \\
\hline X2MnCrNiMo2 2 1 1 & 920 & 1130 & 16 & 310 \\
\hline X2MnNiSiTi4 3 2 1 & 1580 & 1810 & 8 & 610 \\
\hline $\begin{array}{c}\text { Maraging Steel 1 } \\
\text { X2NiCoMo 18 9 5 }\end{array}$ & 2090 & 2150 & 12 & 605 \\
\hline $\begin{array}{c}\text { Maraging Steel 2 } \\
\text { X2NiCoMoTi12 8 8 }\end{array}$ & 1780 & 1953 & 20 & 570 \\
\hline
\end{tabular}

Besides the investigations on low alloyed low carbon steels with a lath martensite microstructure, high nitrogen steels were examined to find out, how far the microstructure consists only of lath martensite. Up to a $\mathrm{N}$-content of $0,25 \mathrm{wt} \%$ the entire microstructure was lath martensite (figure 4). This steel showed a remarkable precipitation hardening up to $550 \mathrm{HV}$. Unfortunately the notch toughness has been about 5 Joule at room temperature, independent of the heat treatment. The corrosion resistance of the high nitrogen steels have been better than the carbon based lath martensites. Other investigation show, that it is possible to achieve a stainless ultra high strength steel by the addition of $12 \% \mathrm{Cr}$ to Maraging Steels. Utsunomiya [15] and Holmquist [16] developed stainless steels with about $9 \% \mathrm{Cr}$ that achieved a considerable precipitation hardening.

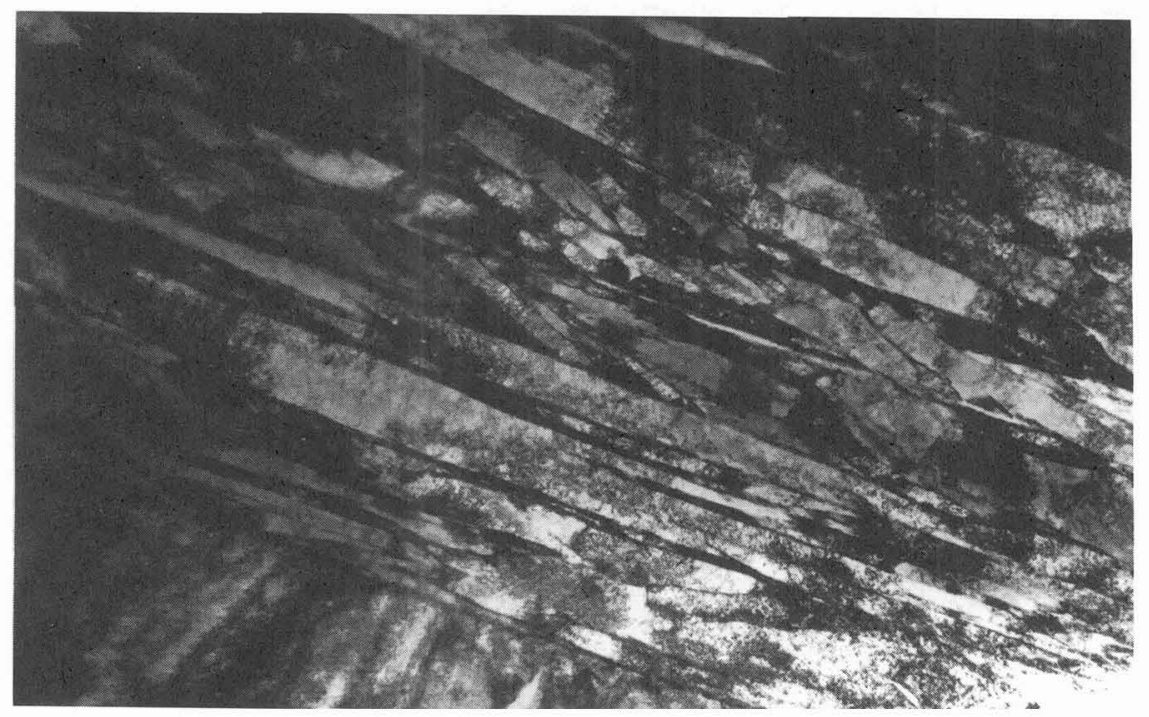

Figure 4: Transmission electron micrograph of a $\mathrm{N}$-alloyed lath martensite Chemical composition: $0,2 \% \mathrm{~N}, 0,038 \% \mathrm{C}, 3,1 \% \mathrm{Mn}, 2,5 \% \mathrm{Cr}$ 


\section{MANUFACTURING OF LATH MARTENSITE}

Lath martensite with a hardness of $300 \mathrm{HV}$ is easy machinable in the as quenched state. As there are hardly any lattice changes in lath martensite during the precipitation of the intermetallic phase, it can be machined in the as quenched state to high precision and subsequently age hardened without any change of the gauge size.

Lath martensite is also highly cold deformable as it has a relatively low n-value of 0,15 . In a cold extrusion process a deformation ratio of 1,5 is possible. The manufacturing of cold extrusion processed components as screws is favourable not only due to its deformability, but also because no tempering process is necessary to achieve the mechanical properties. The yield strength of screws or cold extruded components can be slightly increased by intense work hardening during the deformation process. This makes lath martensite an ideal material for high-strength screws or other fastening elements like rivets.

Even welded joints showed an excellent toughness. Impact tests of submerged arc joints showed a transition temperature of $-40^{\circ} \mathrm{C}$ in the coarse grain zone (figure 5).

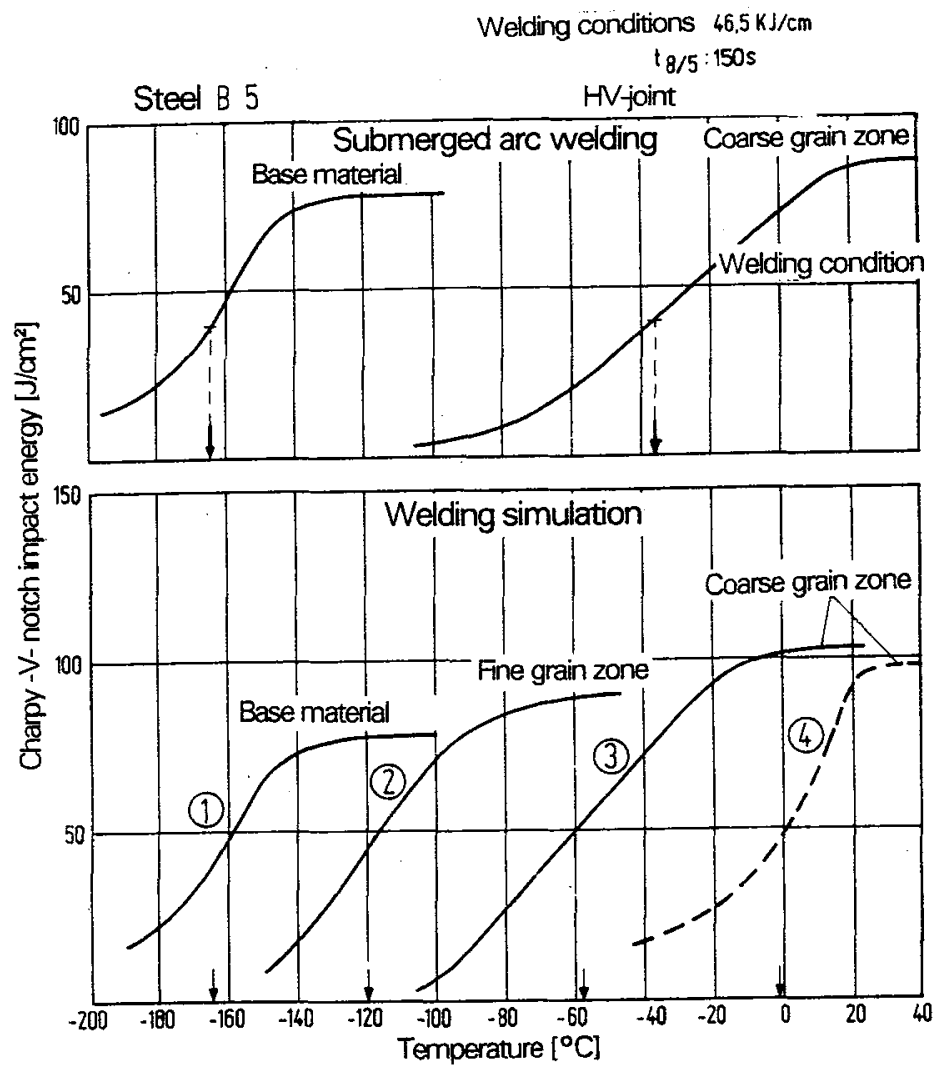

Figure 5: Impact energy of the base material and the coarse grain zone in the welded joint of a low alloyed lath martensite. Chemical composition: $2 \% \mathrm{Mn}, 2 \% \mathrm{Cr}, 1 \% \mathrm{Ni}, 1 \% \mathrm{Mo}, 0,03 \% \mathrm{C}$ 
Due to the thermal stability of the lath martensite microstructure, soldering in the quenched state at about $600^{\circ} \mathrm{C}$ is possible without loss of hardness (figure 6). On the contrary, Maraging Steels offer the possibility to increase the hardness by the precipitation of intermetallic phase during the soldering process. To combine soldering and age-hardening reduces costs and makes it possible to increase dimensional accuracy.

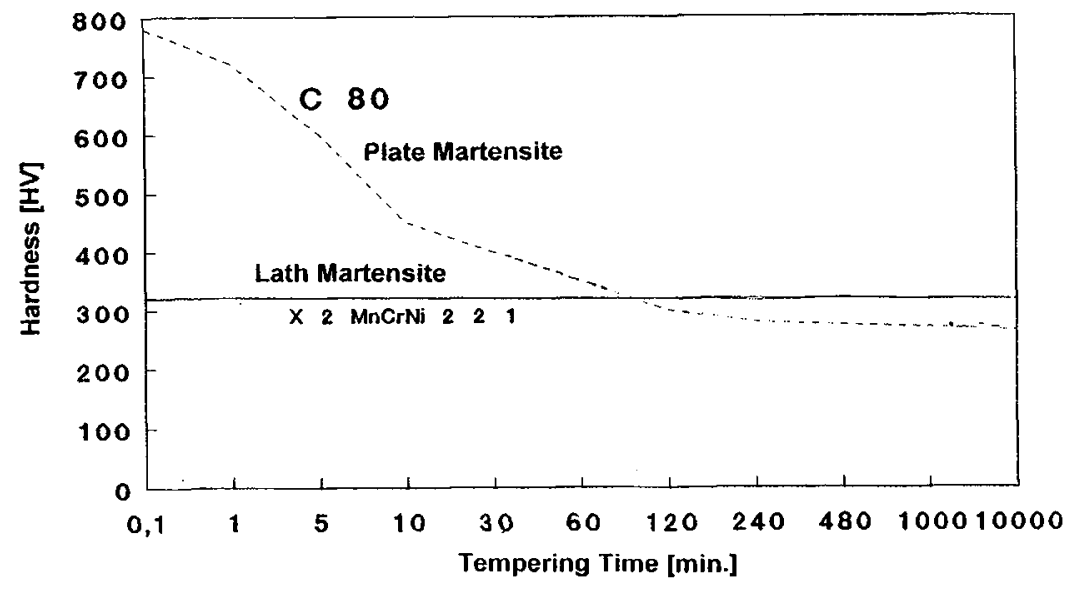

Figure 6: Influence of a tempering treatment on the hardness of plate and lath martensite

In plate martensite too, a comparatively high toughness values can be achieved, if carbon is replaced by nitrogen. The refining influence of nitrides on the austenite grain sizes and the precipitation of fine nitrides during the annealing process leads to impact values three times higher than those of comparable high carbon plate martensite.

\section{TRENDS FOR NEW APPLICATIONS}

Large quantities of steel is increasingly used for automotive applications, where the majority is sheet metal. Automotive applications demand a weight saving construction, which can only be achieved by steels with a tensile strength of about $1000 \mathrm{MPa}$ [17]. At the same time these steels have to exhibit a sufficient toughness. Besides new manufacturing technologies as deep drawing [18], cold extrusion and mechanical joining require a high deformability. As lath martensite meet all these demands and is easy to weld, a future application seems certain. The hot rolling of lath martensite in a sheet metal has already been established.

For high precision wear resistant components age-hardenable lath martensite offers a large range of new applications. These are dies, nozzles, valves and water cooled cores of polymer extrusion moulds. This is 
a new chance for both, the traditional Maraging Steels or the newly developed low alloyed age-hardened lath martensite steels.

\section{SUMMARY}

A comparatively good toughness can be achieved in high strength lath martensite steels. By precipitation of intermetallic phases or nitrides the tensile strength can be improved to $2000 \mathrm{MPa}$. Lath martensite is easy to machine and highly deformable at room temperature. Due to minimal volume changes during the precipitation hardening high precision can be obtained, if a component is manufactured in the as quenched state and subsequently age-hardened. Lath martensite is easy to join by welding or even by soldering during age-hardening process. This makes lath martensite an ideal material to meet demands of modern light weight construction.

\section{References}

[1] K. Yamazaki; M. Oka; et al. Nippon Steel Technical Report No. 64 Jan. (1995) pp. 37-44

[2] M. Umemoto, E, Yoshitake, I. Tamura, Journal for Mart. Science 18 (1983) pp. 2893-2904

[3] I. Tamura, K. Tsuzaki, T. Maki, Journal de Phy. supplem. 12, Tome 43 (1982) pp 551-556

[4] A. Schulz-Beenken, H. Hougardy; EUR-Report "Techn. Forschung Stahl", Brüssel 1990

[5] R. F.Decker, J.T. Eash; A. Goldman; ASM Trans Quart, 55 (1962) 58

[6] E. Hornbogen, K. Rittner; Steel research 58 (1987) p. 172-177

[7] H.-L. Lee; Dissertation RWTH Aachen 1986

[8] W. Patterson; L. Richardson; Trans ASM, 59 (1966) P.71-83

[9] A. Parwardhan, HSLA Steels Technology and Applications; 3-6 Oct. Philadelphia, USA pp. 177-192

[10] H. Riedel; Dissertation RWTH Aachen, 1984

[11] J.P. Naylor; Metall Trans. 10A (1979) p. 861

[12] W. Österle; The Martensitic Transformation in Science and Technology; Ed. E. Hornbogen, N. Jost; Bochum; DGM Informationsgesellschaft, 1989

[13] A. Schulz-Beenken, H. Riedel, H. Hougardy, "Beiträge zu den Grundlagen und zur interdisziplinären Anwendung. DGM Informationsgesellschaft. Verlag, 1991

[14] F. Habiby; T.N. Siddiqui; H. Hussain; A. U1 Haq; A.Q: Kahn; Journal of Mat. Sc. 31 (1996) 305-309

[15] T. Utsuomiya; K. Hosino, ASM Intrn. Conf. on New Developments in Stainless Steel Techn., Detroit, Mchigan US; 17-20 Sept. 1985

[16] M. Holmquist, J. Nilsson, A. Stigenberg; Scripta Metall. Vol 33, No 9, pp1367-1373

[17] Y. Tomota; Higher-strength Steel an it's Future Devlopment, Steel Today\& Tomorrow (1995), nr. 131, pp. 5-8.

[18] T. Heller, J. Esdohr, Hochfestes Warmband für die Stanz- und Presstechnik, Stahl (1997) 1, pp. 34, 37- 39. 